Rev. salud pública. 14 (2): 350-355, 2012

Caso en Salud Pública/Public Health Case

\title{
The molecular diagnosis of pelvic tuberculosis: a case report
}

\section{Diagnóstico molecular de tuberculosis pélvica: reporte de caso}

Álvaro A. Faccini-Martínez ${ }^{1}$, Alejandro Espinal ${ }^{1}$, Jimena Jojoa², Ivonne Díaz ${ }^{3}$, Roger Montes ${ }^{3}$, María Nilse González ${ }^{3}$, Luz Ángela Pescador ${ }^{3}$, Sandra Valderrama-Beltrán ${ }^{3}$ and Wellman Ribón ${ }^{4}$

1 Facultad de Medicina, Universidad Militar Nueva Granda. Bogotá, Colombia. afaccini@gmail. com, aspina199@gmail.com

2 Grupo de Micobacterias, Instituto Nacional de Salud. Bogotá, Colombia.jimmebac@hotmail.com,

3 Hospital Militar Central. Bogotá, Colombia. idiazyamal@gmail.com,rogerma26@gmail.com, marianilse@yahoo.es, luzangelapv@hotmail.com, valderrama@gmail.com

4 Grupo de Inmunología y Epidemiología Molecular, Universidad Industrial de Santander. Bucaramanga, Colombia.wribon@uis.edu.cowellmanribon@yahoo.es

Received 27 $7^{\text {th }}$ July 2011/Sent for Modification $2^{\text {th }}$ April 2012/Accepted $25^{\text {th }}$ April 2012

\section{ABSTRACT}

Tuberculosis is a re-emerging infectious disease. A retrospective analysis was made of the clinical history of a 48-year-old woman in April 2009; she was a secretary at a third-level hospital living in an urban area. Pelvic tubercular infection was suggested as a possible diagnosis; spoligotyping molecular methodology was used on a peritoneal secretion sample to confirm such diagnosis and confirmed the presence of Mycobacterium tuberculosis (octal code 777777777760771 , SIT 53, Family T1).

Key Words: Mycobacterium tuberculosis, tuberculosis, DNA, Colombia (source: $\mathrm{MeSH}, \mathrm{NLM})$.

\section{RESUMEN}

La tuberculosis es una enfermedad infecciosa reemergente. Durante el mes de abril de 2009 se realizó el análisis retrospectivo de la historia clínica de una mujer de 48 años de edad, residente en área urbana, secretaria de un hospital de tercer nivel. Se determinó infección tuberculosa pélvica como diagnóstico presuntivo. Con el fin de confirmar dicho diagnóstico, se realizó la metodología molecular de spoligotyping en muestra de secreción peritoneal y confirmó la presencia de Mycobacterium tuberculosis, código octal 777777777760771 , SIT 53, familia T1.

Palabras Clave: Mycobacterium tuberculosis, tuberculosis, ADN, Colombia (fuente: DeCS, BIREME). 
7 uberculosis (TB) is a re-emerging infectious disease; 9.27 million new cases appeared in 2007 according to the latest WHO report. ( The appearance of multidrug-resistance (MDR) and extensive MDR (XDR) (1) has aggravated the situation. The Colombian Tuberculosis Program (CTP) estimated 10,696 new cases in 2006 (2,3).

Extra-pulmonary TB forms may develop in the same way; pelvic TB is one such form produced by the causal agent's dissemination from a primary focus. It may appear as a consequence of direct sexual contact with a person suffering from genital TB (4) and, rarely, through infected sputum used as a sexual lubricant (5).

Pelvic TB presents nonspecific symptoms (6-9); it accounts for around $30 \%$ of extra-pulmonary TB cases (10), appearing predominantly in 3050 -year old women $(11,12)$ whose fallopian tubes are the most frequently compromised structures (94\%), followed by the endometrium $(60 \%)$, the ovaries (20-30\%) and cervix (1-10\%) $(7,13,14)$.

Clinical case

A 48-year-old woman residing in an urban area, employed as a secretary in a third-level hospital, consulted the emergency services' department of the institution where she was employed on March 9th, 2009, reporting 2 days of cramping pain in the left iliac cavity. Transvaginal ultrasound found complex left adnexal and left hydrosalpinx masses with the pouch free of masses; out-patient treatment was recommended with anti-spasmodic drugs and follow-up medical consultation. The patient consulted again with the same symptoms, accompanied by vaginal burning and itching, on March 14th.

The only positive finding when review systems was that the patient reported subjective, non-quantified weight loss over the last 2 years. The gynecological-obstetric history included two pregnancies, two births (no abortions), 2 caesarean births, 2 live births, the last birth being 17 years ago. Her last period dated from February $18^{\text {th }}, 2009$, and the date of her last PAP exam was March 6th, 2009, which had occurred within the recommended period.

Physical examination concluded that the patient was in good general condition. She experienced pain upon palpitation of the colic zone and left iliac cavity; vaginal examination disclosed a posterior cervix that 
was painful upon palpitation; left adnexa and pouch were palpable and painful. No other findings were observed during the physical examination. A transvaginal ultrasound revealed $35 \times 34 \times 23 \mathrm{~mm}$ left ovary with a $20 \times 20$ $\mathrm{mm}$ cystic image inside it; an elongated-mass was observed with particulate liquid inside it, resulting in a diagnostic finding of left adnexal and left hydrosalpinx masses (Figure 1).

Figure 1. Transvaginal ultrasound take on March 14th, 2009

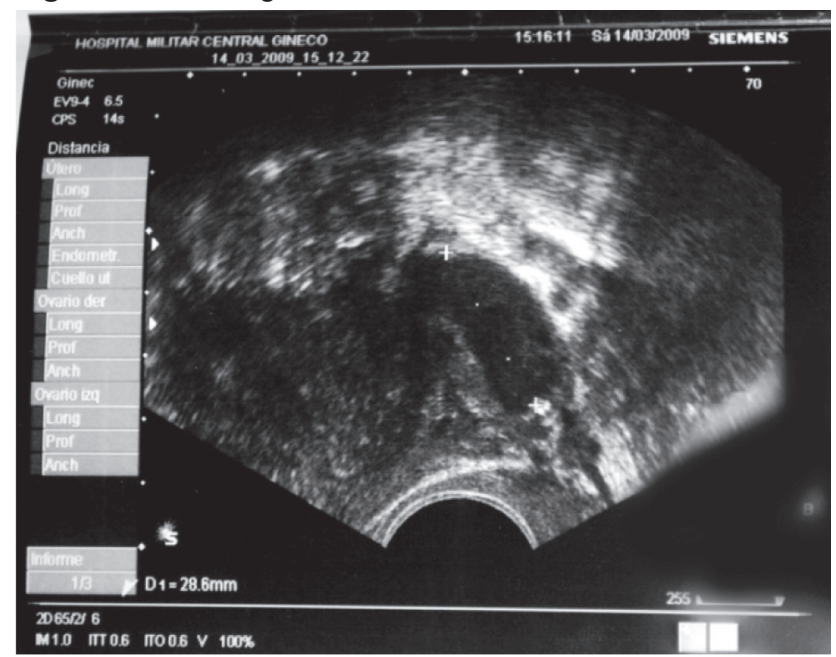

The mage reveals $35 \times 34 \times 23 \mathrm{~mm}$ left ovary with $20 \times 20 \mathrm{~mm}$ cystic image inside it; an elongated-mass was observed with particulate liquid inside it, resulting in a diagnostic finding of left adnexal and left hydrosalpinx masses

The ultrasound results led to carrying out diagnostic and surgical laparoscopy, resulting in the following findings: severe adhesive process involving the left ovarian cavity; dilated tube segment consistent with $4 \times 3$ $\mathrm{cm}$ pyosalpinx; granulamatous lesions were evident throughout the entire peritoneal cavity including the liver, parietal peritoneum, uterus, tubes and bowels. The left ovarian tube abscess was drained; left salpingectomy, peritoneal lavage and left adnexa biopsy were performed.

Complementary paraclinical findings included a negative Elisa test for HIV. A microbiological study of peritoneal secretion reported few polymorphonuclear leukocytes, Gram-negative stain, negative ZN stain, culturing for common bacteria was negative after 72 hours incubation and culturing for mycobacteria was negative following 12 weeks' incubation. 
The pathological study revealed chronic granulamatous inflammation and chronic granulamatous salpingitis suggestive of $\mathrm{TB}$, with negative $\mathrm{ZN}$ and auramine staining (Figure 2); accordingly, a probable diagnosis of pelvic TB was made with the initiation of an 84-dose strictly-supervised, shortterm antituberculosis treatment program.

Figure 2. Pathological study of left adnexa with haematoxylin-eosin staining A

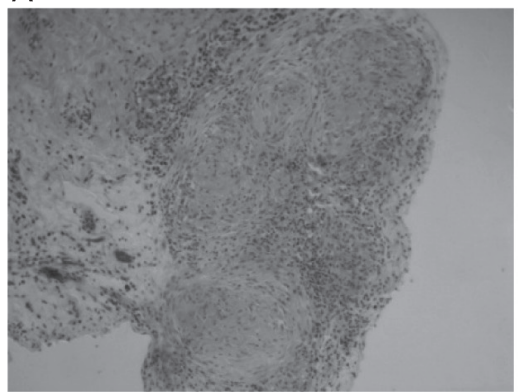

B

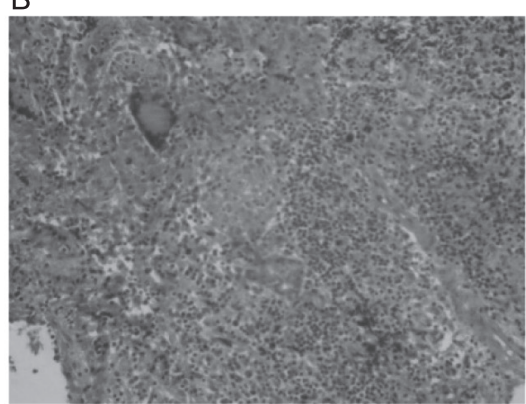

A - Granulamatous formations can be observed with central caseation necrosis, 10X

B - Granulamatous formation with giant Langhans multinucleated cells, suggestive of TB, 40X

The spoligotyping molecular method was used to identify species comprising the $\mathrm{M}$. tuberculosis complex to confirm a diagnosis of pelvic TB. M. tuberculosis species were identified from an aliquot of peritoneal secretion (octal code 7777777777760771, SIT 53, T1 family). According to the Pasteur Institute's database, this genotype has been reported in the USA, Venezuela, Zambia, Zimbabwe, Vietnam and South Africa (15).

The patient tolerated the antituberculosis treatment, completed the prescribed regimen and was successfully discharged from the CTP after 26 weeks.

\section{DISCUSSION}

The current study further recommends that health authorities schedule periodic inspections of the protocols used in the diagnosis of extrapulmonary TB, including conventional TB diagnosis, genotyping methods and strict biosecurity regulation. Microorganism culturing is highlysensitive and allows for complementary tests, such as determining species and susceptibility pattern which are important aspects for effective patient management by the CTP. However, the microorganism's slow growth 
conflicts with early diagnosis in spite of great advances in automated methods having been achieved to this end $(16,17)$.

Molecular methods have greatly contributed towards diagnosing diseases caused by Mycobacterium species during the last two decades and have provided knowledge about these microorganisms' genetic profile (18-20).

The first case of pelvic TB in Colombia using spoligotyping for determination among the seven species comprising the M. tuberculosis complex is documented here (i.e. M. tuberculosis species responsible for this clinical situation). This was also confirmed by the patient's response to treatment and cure. This case confirmed the pressing need for adopting effective molecular methodologies in the diagnosis of extra-pulmonary TB as part of the CTP, aimed at offering accurate and opportune treatment contributing towards decreasing the morbidity-mortality of patients for whom conventional control programme methods are ineffective.

In spite of early initiation of empirical anti-TB treatment in this case (with the aetiological agent's subsequent identification and confirmation by molecular biology methods), many patients are not so fortunate and empirical treatment is not provided or is delayed due to the low clinical suspicion index and conventional laboratory methods which are ineffective in identifying and isolating $\mathrm{M}$. tuberculosis in extra-pulmonary forms of the illness. Molecular biology methods are always based on strong clinical suspicion and histopathological findings, thereby offering a promising scenario for extra-pulmonary TB diagnosis $(21,22)$

Acknowledgments: We would like to thank the Universidad Militar Nueva Granada, Hospital Militar, Instituto Nacional de Salud and the Universidad Industrial de Santander for their support

\section{REFERENCES}

1. World Health Organization. Global Tuberculosis Control 2009 Epidemiology, Strategy, Financing. Ginebra: WHO press; 2009.

2. Ministerio de la Protección Social. Situación de salud en Colombia. Indicadores básicos 2006. Bogotá, D.C.: Vigilancia en Salud Pública; 2006. [Internet]. Disponible en: http://www.minproteccionsocial.gov.co/ Consultado: 10 de noviembre de 2009

3. Castiblanco CA, Ribón W. Coinfección de tuberculosis en pacientes con VIH/SIDA: un análisis según las fuentes de información en Colombia. Infectio. 2006;10:232-42. 
4. Sutherland AM, Glen ES, MacFarlane JR. Transmission of genito-urinary tuberculosis. Health Bull. 1982;40:87-91.

5. Chowdhury NN. Overview of tuberculosis of the female genital tract. J Indian Med Assoc. 1996; 94:345-6, 361.

6. Gupta N, Sharma JB, Mittal S, Singh N, Misra R, Kukreja M. Genital tuberculosis in Indian infertility patients. Int J Gynaecol Obstet. 1997; 97:135-8.

7. Matos MJ, Bacelar MT, Pinto P, Ramos I. Genitourinary tuberculosis. Eur J Radiol. 2005;55:181-7.

8. Hatami M. tuberculosis of the female genital tract in Iran. Arch Iranian Med. 2005; 8:32-5.

9. García G, García AJ, Gómez EI, Saldarriaga Cl. Tuberculosis peritoneal en una paciente con ascitis y masa anexial. reporte de un caso. Rev Colomb Obstet Ginecol. 2006;57:62-5.

10. Wise GJ, Marella VK. Genitourinary manifestations of tuberculosis. Urol Clin North Am. 2003;30:111-21.

11. Jacob JT, Mehta AK, Leonard MK. Acute forms of tuberculosis in adults. Am J Med. 2009;122:12-7.

12. García F, Motta L, Castillo F, Ureta A, Delgado VM. Tuberculosis pélvico-peritoneal simulando cáncer de ovario con CA 125 elevado. Ginecol Obstet. 1998;44:69-71.

13. Matos MJ, Bacelar MT, Pinto P, Ramos I. Genitourinary tuberculosis. Eur J Radiol. 2005;55: 181-7.

14. Sutherland AM. Gynaecological tuberculosis: analysis of a personal series of 710 cases. Aust NZJ Obstet Gynaecol.1985; 25:203-7.

15. Institut Pasteur de la Guadaloupe. Tuberculose et Mycobacteries. SPOLDB4, sorted by increasing binary spoligotype description. [Internet]. Disponible en: http://www. pasteur-guadeloupe.fr/tb/spoldb4/spoldb4sorted.pdf Consultado: febrero de 2009

16. Vicent V, Gutiérrez MC. Mycobacterium: Laboratory characteristics of slowly growing mycobacteria. Manual of Clinical Microbiology. $9^{\mathrm{a}}$ ed. Washington D. C.: American Society for Microbiology; 2007. pp. 573-88.

17. Dinnes J, Deeks J, Kunst H, Gibson A, Cummins E, Waugh N, et al. A systematic review of rapid diagnostic tests for the detection of tuberculosis infection. Health Technol Assess. 2007; 11:1-196.

18. Burgos MV, Méndez JC, Ribón W. Molecular Epidemiology of Tuberculosis: Methodology and Applications. Biomédica. 2004; 24:188-201.

19. Puerto G, Castro CM, Ribón W. Reacción en cadena de la polimerasa: una contribución para el diagnóstico de la tuberculosis extrapulmonar y de las micobacteriosis. Infectio. 2007;11:87-94.

20. Castro CM, Puerto G, García LM, Orjuela DL, Llerena C, Garzón MC, et al. Identificación molecular de micobacterias no tuberculosas mediante el análisis de los patrones de restricción, Colombia 1995-2005. Biomédica. 2007; 27:439-46.

21. Alcaide F. Nuevos métodos de identificación de Micobacterias. Enferm Infecc Microbiol Clin. 2006;24:53-7.

22. Domínguez J, Blanco S, Lacoma A, García N, Prat C, Ausina V. Utilidad de la biología molecular en el diagnóstico microbiológico de las infecciones por micobacterias. Enferm Infecc Microbiol Clin. 2008;26: 33-41. 